\title{
Ocena propozycji zmian przepisów art. 156 i art. 158 Kodeksu postępowania administracyjnego ${ }^{1}$
}

\begin{abstract}
Assessment of the proposed amendment of Article 156 and 158 of the Code of Administrative Proceedings (WAP-2659/17): Amendments of the Code of Administrative Proceedings, suggested in the assessed petition, introduce an exclusion of the possibility of declaring an administrative decision invalid, if the decision has been issued without legal basis or with a gross infringement of law, after 10 years from the day the decision has been delivered or published. The proposed solution consisting of an application of the limitation period set out in Article 156 para. 2 of the Code even to such decisions issued without legal basis or with the gross infringement of law which have not been a basis for acquiring a right or expectative of a right (wider than in the Constitutional Tribunal's judgment, ref. no. P 46/13) - stays, in the author's opinion, in accordance with Article 2 of Polish Constitution and it could be regarded as optimally balancing the principle of the rule of law, the principle of legal certainty and the principle of the protection of legitimate expectation. Moreover, the author claims that introducing the new Article 158 para. 3 of the Code, according to which a declaration a questioned decision as invalid due to its issue without legal basis or with a gross infringement of law of issue of a decision with an infringement of law shall constitute grounds for declaration of invalidity of a decision issued on the basis of the former one, is justified.
\end{abstract}

Keywords: the Code of Administrative Proceedings, petition

Słowa kluczowe: Kodeks postępowania administracyjnego, petycja

Profesor doktor hab. nauk prawnych, Uniwersytet Wrocławski, ekspert ds. legislacji BAS; marek.szydlo@uwr.edu.pl.

\section{Przedmiot petycji}

Petycja będąca przedmiotem niniejszej opinii prawnej (dalej: Petycja) postuluje dokonanie zmian w przepisach art. 156 i art. 158 ustawy z 14 czerwca 1960 r. - Kodeks postępowania administracyjnego (t.j. Dz.U. 2017, poz. 1257, ze zm.; dalej: k.p.a.). Zmiany te mają prowadzić do wykluczenia w polskim prawie

1 Opinia sporządzona 23 kwietnia 2018 r. na zlecenie przewodniczącego Komisji do Spraw Petycji; BAS-WAP 2659/17. 
możliwości stwierdzania nieważności decyzji administracyjnych wydanych bez podstawy prawnej lub z rażącym naruszeniem prawa, jeżeli od dnia doręczenia lub ogłoszenia danej decyzji upłynęło dziesięć lat. Dla osiągnięcia tego stanu rzeczy Petycja postuluje zmianę treści obecnego art. $156 \$ 2$ k.p.a. polegającą na tym, że w przepisie tym wśród rodzajów decyzji, których nieważności nie można stwierdzić po upływie dziesięciu lat od dnia ich doręczenia lub ogłoszenia, zostaną wymienione również decyzje określone w art. $156 \$ 1$ pkt 2 k.p.a., czyli decyzje wydane bez podstawy prawnej lub z rażącym naruszeniem prawa. Ponadto Petycja wnioskuje o dodanie nowego przepisu art. $158 \$ 3$ k.p.a. o następującym brzmieniu: „Stwierdzenie wydania zaskarżonej decyzji administracyjnej z naruszeniem prawa stanowi podstawę do stwierdzenia wydania $\mathrm{z}$ naruszeniem prawa decyzji administracyjnej, która została wydana na podstawie takiej zaskarżonej decyzji". W Petycji proponuje się przy tym ustanowienie reguły intertemporalnej mówiącej o tym, że do postępowań o stwierdzenie nieważności decyzji wszczętych przed wejściem w życie ustawy implementującej postulaty Petycji stosuje się przepisy dotychczasowe. Twórcy Petycji proponują, aby ustawa wdrażająca postulaty Petycji weszła w życie w terminie 14 dni od jej ogłoszenia.

\section{Obecny stan prawny i wyrok Trybunału Konstytucyjnego w sprawie P 46/13}

W obecnym stanie prawnym art. $156 \$ 1$ k.p.a. nakazuje właściwym organom administracji publicznej stwierdzanie nieważności decyzji administracyjnych dotkniętych którąś z następujących kwalifikowanych wad: 1) decyzja została wydana $z$ naruszeniem przepisów o właściwości; 2) decyzja została wydana bez podstawy prawnej lub z rażącym naruszeniem prawa; 3) decyzja dotyczy sprawy już poprzednio rozstrzygniętej inną decyzją ostateczną albo sprawy, którą załatwiono milcząco; 4) decyzja została skierowana do osoby niebędącej stroną w sprawie; 5) decyzja była niewykonalna w dniu jej wydania i jej niewykonalność ma charakter trwały; 6) decyzja w razie jej wykonania wywołałaby czyn zagrożony karą; 7) decyzja zawiera wadę powodującą jej nieważność z mocy prawa. Jednocześnie art. $156 \$ 2$ k.p.a. stanowi, że: [n] ie stwierdza się nieważności decyzji $z$ przyczyn wymienionych $w \$ 1$ pkt 1, 3, 4 i 7, jeżeli od dnia jej doręczenia lub ogłoszenia upłynęło dziesięć lat, a tak̇̇e gdy decyzja wywołała nieodwracalne skutki prawne. Art. $156 \$ 2$ k.p.a. ustanawia zatem negatywne przesłanki stwierdzenia nieważności decyzji administracyjnej, do których należą, po pierwsze, upływ dziesięcioletniego terminu od dnia doręczenia lub ogłoszenia decyzji (nazywany też przesłanką przedawnienia) ${ }^{2}$ oraz, po drugie, fakt wywołania przez decyzję

2 Por. M. Jaśkowska [w:] M. Jaśkowska, A. Wróbel, Kodeks postępowania administracyjnego. Komentarz Lex, Warszawa 2011, s. 981. 
nieodwracalnych skutków prawnych. Z art. $156 \$ 2$ k.p.a. wynika, że o ile negatywna przesłanka stwierdzenia nieważności decyzji w postaci wywołania przez decyzję nieodwracalnych skutków prawnych ma zastosowanie do decyzji dotkniętych którąkolwiek z kwalifikowanych wad określonych w art. $156 \$ 1$ k.p.a., o tyle negatywna przesłanka stwierdzenia nieważności decyzji w postaci upływu czasu ma zastosowanie tylko do decyzji dotkniętych kwalifikowanymi wadami określonymi w art. $156 \$ 1$ pkt 1 (decyzja została wydana z naruszeniem przepisów o właściwości), pkt 3 (decyzja dotyczy sprawy już poprzednio rozstrzygniętej inną decyzją ostateczną albo sprawy, którą załatwiono milcząco), pkt 4 (decyzja została skierowana do osoby niebędącej stroną w sprawie) i pkt 7 (decyzja zawiera wadę powodującą jej nieważność z mocy prawa) Kodeksu postępowania administracyjnego. Oznacza to, że de lege lata jest prawnie dopuszczalne stwierdzenie nieważności decyzji wydanej bez podstawy prawnej lub z rażącym naruszeniem prawa (a także decyzji trwale niewykonalnej w dniu jej wydania oraz decyzji, która w razie jej wykonania wywołałaby czyn zagrożony karą) bez względu na czas, jaki upłynął od dnia doręczenia lub ogłoszenia danej decyzji. Tak więc upływ dziesięcioletniego lub dłuższego terminu od dnia doręczenia lub ogłoszenia decyzji wydanej bez podstawy prawnej lub z rażącym naruszeniem prawa (a także decyzji trwale niewykonalnej w dniu jej wydania oraz decyzji, która w razie jej wykonania wywołałaby czyn zagrożony karą) nie uniemożliwia stwierdzenia nieważności danej decyzji, gdyż do takich decyzji przesłanka przedawnienia wynikająca $z$ art. $156 \$ 2$ k.p.a. nie ma de lege lata zastosowania. Merytorycznym uzasadnieniem dla prawnej dopuszczalności stwierdzania nieważności decyzji określonych w art. $156 \$ 2$ pkt 2, 5 i 6 k.p.a. bez względu na upływ czasu od dnia ich wejścia do obrotu prawnego jest okoliczność, iż decyzje te są dotknięte najpoważniejszymi z kwalifikowanych wad określonych w art. $156 \$ 1$ k.p.a., tak iż upływ czasu nie powinien sanować ich niezgodności z porządkiem prawnym.

Przepis art. $158 \$ 2$ k.p.a. stanowi, że w odniesieniu do decyzji administracyjnych, których nieważności nie można stwierdzić z uwagi na wystąpienie którejś z negatywnych przesłanek określonych w art. $156 \$ 2$ k.p.a. (tj. przesłanek w postaci upływu czasu lub nastąpienia nieodwracalnych skutków prawnych) organ administracji publicznej powinien ograniczyć się do stwierdzenia wydania zaskarżonej decyzji z naruszeniem prawa oraz wskazania okoliczności, z powodu których nie stwierdził nieważności decyzji. Rzecz jasna, przewidzianej w art. 158 $\$ 2$ k.p.a. decyzji stwierdzającej wydanie zaskarżonej decyzji z naruszeniem prawa oraz wskazującej jako powód niemożności stwierdzenia nieważności zaskarżonej decyzji okoliczność w postaci przedawnienia nie można wydać wobec decyzji wydanej bez podstawy prawnej lub z rażącym naruszeniem prawa, gdyż jak już powiedziano - stwierdzenie nieważności decyzji wydanej bez podstawy prawnej lub z rażącym naruszeniem prawa jest prawnie dopuszczalne w każdym czasie, bez względu na termin, jaki upłynął od dnia doręczenia lub ogłoszenia takiej decyzji. 
W wyroku z 12 maja 2015 r. w sprawie o sygn. akt P 46/13 Trybunał Konstytucyjny (TK) uznał, że: Art. 156 \$ 2 ustawy z dnia 14 czerwca 1960 r. - Kodeks postępowania administracyjnego (Dz.U. z 2013 r. poz. 267, ze zm.) w zakresie, w jakim nie wyłacza dopuszczalności stwierdzenia nieważności decyzji wydanej $z$ rażacym naruszeniem prawa, gdy od wydania decyzji nastapił znaczny upływ czasu, a decyzja była podstawa nabycia prawa lub ekspektatywy, jest niezgodny $z$ art. 2 Konstytucji Rzeczypospolitej Polskiej ${ }^{3}$. Do tego rodzaju konkluzji Trybunał doszedł po dokonaniu wyważenia ze sobą dwóch konstytucyjnych zasad, które leżą u podstaw przewidzianej w Kodeksie postępowania administracyjnego instytucji stwierdzania nieważności decyzji oraz instytucji negatywnych przesłanek stwierdzania nieważności decyzji. Chodzi mianowicie o konstytucyjne zasady: praworządności czy też legalizmu (z jednej strony) oraz pewności prawa i zaufania obywatela do państwa (z drugiej strony).

W tym kontekście TK stwierdził, że konstytucyjna zasada praworządności (legalizmu), odnosząca się również do działalności orzeczniczej organów administracji publicznej, jest uzasadnieniem dla konstrukcji prawnych, których celem jest wyeliminowanie z obrotu wadliwej decyzji, takich jak konstrukcja stwierdzenia nieważności decyzji. Rezultatem zastosowania takich konstrukcji jest przywrócenie stanu zgodnego z prawem, a co najmniej eliminacja stanu niezgodnego z prawem. Bezpośrednim rezultatem stwierdzenia nieważności decyzji jest zniesienie wynikającego z niej stanu niezgodności z prawem, który ma charakter kwalifikowany, tj. opisany w art. $156 \$ 1$ k.p.a. (pkt III.5.2 uzasadnienia). To dopuszczenie przez ustawodawcę stwierdzania nieważności decyzji administracyjnych dotkniętych kwalifikowanymi wadami określonymi w art. $156 \$ 1$ k.p.a., dokonane $\mathrm{w}$ interesie urzeczywistniania konstytucyjnej zasady praworządności (legalizmu), stanowi wyjątek od reguły trwałości decyzji administracyjnych, czyli od reguły, dzięki której realizowane są konstytucyjne zasady pewności prawa i zaufania obywatela do państwa. Reguła trwałości decyzji administracyjnych służy realizacji istotnych wartości, jakimi są ochrona porządku prawnego, stabilności obrotu prawnego, zaufania do organów państwa i samego prawa, a przede wszystkim - ochrona praw nabytych. Trwałość decyzji ma duże znaczenie dla stabilizacji skutków prawnych wynikających z decyzji i realizuje potrzebę zagwarantowania bezpieczeństwa sytuacji prawnej obywateli. To właśnie z uwagi na chęć zagwarantowania trwałości decyzji ustawodawca w niektórych przypadkach wyłącza możliwość stwierdzenia nieważności decyzji dotkniętej kwalifikowanymi wadami. W takich przypadkach ustawodawca wychodzi z uzasadnionego praktycznie założenia, że pomijanie w sferze normatywnej wszelkich skutków prawnych wadliwej decyzji może prowadzić do niekorzystnych następstw społeczno-ekonomicznych i może być niezgodne z zasadami pewności prawa i za-

3 OTK-A ZU 2015, nr 5, poz. 62. 
ufania obywatela do państwa. Zasady te przemawiają za trwałością decyzji administracyjnej ${ }^{4}$.

$\mathrm{W}$ tym kontekście TK podkreślił, że żadna $\mathrm{z}$ rozważanych przez niego powyższych zasad - tj. ani zasada praworządności, ani też zasada pewności prawa i zaufania obywatela do państwa - nie ma charakteru bezwzględnego i do obu z nich dopuszczalne są wyjątki. Przy czym na gruncie zasady praworządności trzeba rozróżnić nakaz działania organów administracji publicznej na podstawie i w granicach prawa, od którego nie ma wyjątków (a tym samym zasada ta nie doznaje ograniczeń), oraz nakaz eliminowania $\mathrm{z}$ obrotu aktów administracyjnych wydanych z naruszeniem zasady praworządności, który może podlegać ograniczeniom, w tym $\mathrm{z}$ uwagi na zasadę zaufania obywatela do państwa i zasadę pewności prawa (pkt III.9.2 uzasadnienia). Zdaniem Trybunału niezbędne jest ustanowienie odpowiednich granic dopuszczalności stwierdzenia nieważności decyzji administracyjnych, tak aby reguła trwałości decyzji organów władzy publicznej nie stawała się jedynie pozorna ${ }^{5}$. Taka pozorność występowałaby nie tylko wtedy, gdyby ustawodawca nie przewidywał ograniczeń wzruszalności ostatecznych decyzji, ale również wtedy, gdyby ograniczenia te nie były wystarczające dla zachowania zasady zaufania obywatela do państwa i zasady pewności prawa (pkt III.9.4 uzasadnienia). TK stwierdzil, że: [u]stawodawca nie może z jednej strony deklarować trwałości decyzji z uwagi na jej ostateczność, a $z$ drugiej strony przewidywać, nieograniczona terminem, możliwość wzruszania decyzji, na podstawie której strona nabyła prawo lub ekspektatywę. W szczególności występuje to $w$ razie powołania się na (...) otwarta i nieostra przesłankę (wadę) „rażacego naruszenie prawa" (pkt III.9.4 uzasadnienia).

W dalszej kolejności Trybunał Konstytucyjny podkreślił, że ustawodawca, określając przesłanki stwierdzania nieważności decyzji oraz zakres ich zastosowania, powinien brać pod uwagę zarówno zasadę praworządności, jak też zasady pewności prawa i zaufania obywatela do państwa, gdyż wszystkie one mieszczą się w klauzuli państwa prawnego przewidzianej w art. 2 Konstytucji. Przesłanek stwierdzania nieważności decyzji nie można oceniać wyłącznie z punktu widzenia tego aspektu zasady praworządności, który uzasadnia rozwiązania prawne zmierzające do eliminacji z obrotu wadliwych decyzji administracyjnych (pkt III.10.1 uzasadnienia). Zdaniem Trybunału: [z]asada praworządności nie uzasadnia rozwiązania prawnego umożliwiajacego stwierdzenie nieważności decyzji administracyjnej, jeśli decyzja ta korzystała przez kilkadziesiąt lat $z$ do-

$4 \quad$ Pkt III.5.1 uzasadnienia, z powołaniem się na M. Zdyb, J. Stelmasiak, Zasady ogólne kodeksu postępowania administracyjnego, Lublin 1999, s. 116, oraz M. Kamiński, Nieważność decyzji administracyjnej. Studium teoretyczne, Warszawa-Kraków 2006, s. 243.

5 W tym kontekście TK powołał się na swój wcześniejszy wyrok z 28 lutego 2012 r. w sprawie o sygn. akt K 5/11, OTK-A ZU 2012, nr 2, poz. 16. 
mniemania zgodności z prawem, wywołuje skutki polegające na nabyciu prawa lub ukształtowaniu ekspektatywy nabycia praw przez jej adresatów, a dodatkowo przesłanka stwierdzenia nieważności decyzji ma charakter niedookreślony i jej wykładnia ukształtowała się w orzecznictwie na długo po wydaniu decyzji. W sytuacji, w której występuje nagromadzenie powyższych okoliczności, zasada praworząności nie służyłaby realizacji zasady pewności prawa. Ponieważ stwierdzenie nieważności decyzji może powodować zmianę ukształtowanej od kilkudziesięciu lat sytuacji prawnej adresatów decyzji, nie służyłoby ono też realizacji zasady zaufania obywatela do państwa $i$ stanowionego przez nie prawa i zasady pewności prawa. Przewidziane $w$ art. $156 \$ 2$ k.p.a. rozwiązanie prawne (...) [polegające na dopuszczeniu stwierdzania nieważności decyzji wydanej z rażącym naruszeniem prawa bez względu na to, jak długi okres upłynął od wydania decyzji - przyp. M.S.] stanowi nadmierne ograniczenie tych konstytucyjnych zasad (pkt III.10.1 uzasadnienia).

W omawianym wyroku w sprawie o sygn. P 46/13 Trybunał podkreślił, że korzystanie przez osobę z praw wynikających z aktu administracyjnego jest wykonywaniem uprawnień zagwarantowanych jej przez organ władzy publicznej. Brak wyłączenia dopuszczalności stwierdzenia nieważności decyzji administracyjnej z przyczyny (wady) określonej w art. $156 \$ 1$ pkt 2 in fine k.p.a. (tj. rażącego naruszenia prawa przy wydawaniu decyzji) po znacznym upływie czasu skutkuje destabilizacją porządku prawnego, jeśli decyzją przyznano stronie ekspektatywę nabycia prawa, z której zamierza ona skorzystać. Stabilizacja stosunków administracyjnoprawnych po upływie określonego czasu leży w interesie porządku publicznego (pkt III.10.3 uzasadnienia). Zdaniem TK unormowanie wynikające $\mathrm{z}$ art. $156 \$ 2$ k.p.a. powinno stanowić kompromis między zasadą praworządności (rozumianą w tej sytuacji jako nakaz uchylenia decyzji wydanych z rażącym naruszeniem prawa) a zasadą trwałości decyzji (rozumianą jako ograniczenie środków, które mogą wyeliminować decyzję z obrotu). Przepis art. $156 \$ 2$ k.p.a. w obecnym brzmieniu narusza taką równowagę. Jest tak chociażby dlatego, że niedookreślony charakter przesłanki rażącego naruszenia prawa powoduje, iż z czasem wzrasta ryzyko prawne, polegające na możliwości wykształcenia się odmiennej linii orzeczniczej zarówno w stosunku do norm materialnych i procesowych, które legły u podstaw wydanej decyzji, jak i samej przesłanki rażącego naruszenia prawa. W ten sposób, wobec braku ograniczenia czasowego możliwości stwierdzenia nieważności decyzji wydanej z rażącym naruszeniem prawa, ryzyko wadliwego działania administracji może zostać w sposób nieograniczony przeniesione na adresata wadliwej decyzji (pkt III.10.4 uzasadnienia). To zaś doprowadziło sąd konstytucyjny do konkluzji, iż: [d]ziałanie organów państwa na podstawie prawa, będące przejawem zasady praworzadności (legalizmu), nie oznacza bezwzględnego obowiązku eliminowania z obrotu wadliwych decyzji, na podstawie których strona nabyła prawo lub jego ekspektatywę (w szczególności jeżeli z takim nabyciem powiazane było powstanie obowiązku państwa), po upływie 
znacznego czasu od wydania tego aktu administracyjnego. Takie aspekty $i$ konsekwencje zasady praworządności sa bowiem ograniczone przez jej inne oblicze, tj. potrzebę stabilizacji stanów społeczno-gospodarczych ukształtowanych moca aktu administracyjnego, a ponadto przez zasadę zaufania obywatela do państwa, $w$ tym zasade pewności prawa, które wynikaja $z$ art. 2 Konstytucji. $Z$ powyższych względów Trybunat uznat, że art. $156 \$ 2$ k.p.a. w zakresie, $w$ jakim nie wyłacza dopuszczalności stwierdzenia nieważności decyzji wydanej z rażącym naruszeniem prawa, gdy od wydania decyzji nastapił znaczny uptyw czasu, a decyzja była podstawa nabycia prawa lub ekspektatywy, jest niezgodny $z$ art. 2 Konstytucji (pkt III.10.5 uzasadnienia). Trybunał podkreślił przy tym, że nie przesądza on bynajmniej o tym, czy właściwym sposobem realizacji jego wyroku jest przewidziany obecnie $\mathrm{w}$ art. $156 \$ 2$ k.p.a. dziesięcioletni termin prekluzyjny, który ogranicza stwierdzenie nieważności decyzji administracyjnych obarczonych niektórymi innymi wadami. Ustawodawca dysponuje bowiem swobodą w wyborze instrumentów prawnych służących realizacji wskazanych przez Trybunał wartości konstytucyjnych (pkt III.10.7 uzasadnienia).

Do chwili obecnej wyrok TK w sprawie o sygn. P 46/13 nie został jeszcze przez ustawodawcę wykonany, co oznacza, że w polskim porządku prawnym nadal istnieje przepis (tzn. art. $156 \$ 2$ k.p.a.), który w swoich skutkach prawnych, $\mathrm{z}$ uwagi na zbyt wąski zakres swojego normowania i zastosowania, narusza art. 2 Konstytucji. W Senacie obecnej kadencji została podjęta próba naprawienia tego pominięcia prawodawczego, które wytknął polskiemu ustawodawcy TK w przywołanym wyżej wyroku. W tym celu Komisja Ustawodawcza Senatu przygotowała projekt ustawy o zmianie ustawy - Kodeks postępowania administracyjnego (druk senacki nr 154). Projekt ten został zgłoszony w dniu 22 kwietnia 2016 r., jednakże 19 października 2016 r. został on przez wnioskodawców wycofany.

Należy dodać, że wyrok TK w sprawie o sygn. P 46/13 nie doprowadził do derogacji żadnego przepisu Kodeksu postępowania administracyjnego, gdyż wyrok ten dotyczył tzw. pominięcia prawodawczego ${ }^{6}$, miał on charakter jedynie zakresowy $^{7}$, a ponadto został wydany $\mathrm{w}$ odpowiedzi na pytanie prawne zadane przez sąd powszechny w trybie art. 193 Konstytucji. Przy czym szczególna treść oraz kontekst tego pytania prawnego zdeterminowały mocno samą finalną tezę wypowiedzianą przez sąd konstytucyjny w tym wyroku, co w rezultacie sprawia, że ustawodawca, wykonując ten wyrok, nie musi tego koniecznie czynić poprzez

6 Na temat pominięcia prawodawczego oraz odróżnienia go od zaniechania prawodawczego zob. np. P. Tuleja, Zaniechanie ustawodawcze [w:] Ustroje, doktryny, instytucje polityczne. Ksiega jubileuszowa Profesora zw. dra hab. Mariana Grzybowskiego, red. J. Czajowski, Kraków 2007, s. 398 i n.; wyrok TK z 6 listopada 2012 r. w sprawie o sygn. akt K 21/11, OTK-A ZU 2012, nr 10, poz. 119.

7 Por. T. Woś, Wyroki interpretacyjne i zakresowe w orzecznictwie Trybunału Konstytucyjnego, „Studia Iuridica Lublinensia” 2016, t. XXV, nr 3, s. 985 i n., oraz wskazana tam dalsza literatura. 
literalne i dosłowne przeniesienie owej finalnej tezy TK do przepisów Kodeksu postępowania administracyjnego. De lege ferenda ustawodawca powinien natomiast uwzględnić zasadniczą myśl wypowiedzianą w wyroku TK o sygn. P 46/13, że nawet decyzje administracyjne dotknięte kwalifikowanymi wadami nie powinny być po upływie dłuższego czasu eliminowane z powodu tych wad $z$ obrotu prawnego, gdyż za ich dalszym obowiązywaniem przemawia wynikająca z art. 2 Konstytucji zasada pewności prawa i zaufania obywatela do państwa.

\section{Przewidziane w Petycji zastosowanie przesłanki przedawnienia $z$ art. 156 § 2 k.p.a. do decyzji wydanych bez podstawy prawnej}

Proponowana w Petycji treść art. $156 \$ 2$ k.p.a. jest w dwóch istotnych aspektach szersza (dalej idąca) niż zasadnicza teza wypowiedziana przez Trybunał Konstytucyjny w wyroku w sprawie o sygn. P 46/13. Pierwszy aspekt dotyczy rodzajów kwalifikowanych wad decyzji, o których jest mowa w art. $156 \$ 2$ k.p.a., natomiast drugi aspekt dotyczy treści i skutków prawnych decyzji, do których odnosi się art. $156 \$ 2$ k.p.a. Zostaną one omówione w kolejnych częściach niniejszej opinii prawnej.

I tak, proponowany w Petycji zakres kwalifikowanych wad decyzji wymienionych w art. $156 \$ 2$ k.p.a. jest szerszy w stosunku do tego, o czym była mowa w wyroku TK w sprawie o sygn. 46/13. Mianowicie, o ile Trybunał Konstytucyjny w tym wyroku uznał, że art. $156 \$ 2$ k.p.a. jest niezgodny z art. 2 Konstytucji w zakresie, w jakim nie czyni przesłanki przedawnienia przesłanką negatywną stwierdzania nieważności decyzji wydanych z rażącym naruszeniem prawa, o tyle w Petycji proponuje się, aby przewidziana w art. $156 \$ 2$ k.p.a. przesłanka przedawnienia była przesłanką negatywną stwierdzania nieważności nie tylko decyzji wydanych z rażącym naruszeniem prawa, ale również decyzji wydanych bez podstawy prawnej. W konsekwencji, pod rządami przepisów proponowanych w Petycji po upływie dziesięciu lat od doręczenia lub ogłoszenia decyzji nie będzie prawnie dopuszczalne stwierdzenie nieważności decyzji wydanej z rażącym naruszeniem prawa lub wydanej bez podstawy prawnej.

W wyroku w sprawie o sygn. P 46/13 Trybunał odniósł się jedynie do kwalifikowanej wady decyzji w postaci wydania decyzji z rażącym naruszeniem prawa (a nie do wady w postaci wydania decyzji bez podstawy prawnej) i sporą część swojej argumentacji poświęcił wyjaśnianiu, dlaczego, jego zdaniem, decyzja wydana $\mathrm{z}$ rażącym naruszeniem prawa powinna korzystać po upływie znacznego okresu z przymiotu trwałości i nie powinna być uchylana w trybie stwierdzenia jej nieważności. W tym kontekście TK powołał się w szczególności na dalece niedookreślony i ocenny charakter przesłanki „rażącego naruszenia prawa” (w rozumieniu art. $156 \$ 1$ pkt 2 in fine k.p.a.) oraz na okoliczność, iż rozumienie 
tej przesłanki w orzecznictwie organów administracji i sądów może ewoluować, powodując wzmacnianie się efektu niepewności prawnej towarzyszącej adresatowi danej decyzji administracyjnej (pkt III.6 i III.7.2 uzasadnienia). Tak więc to w dużej mierze sama treść i charakter przesłanki rażącego naruszenia prawa (w rozumieniu art. $156 \$ 1$ pkt 2 in fine k.p.a.) doprowadziły TK do konkluzji, iż decyzje obarczone tego rodzaju wadami nie powinny w świetle art. 2 Konstytucji być wyłączane spod działania przesłanki przedawnienia przewidzianej w art. 156 $\$ 2$ k.p.a. - przeciwnie, przesłanka przedawnienia $\mathrm{z}$ art. $156 \$ 2$ k.p.a. również i do takich decyzji powinna mieć zastosowanie.

Nieco inaczej rzecz się przedstawia z decyzjami administracyjnymi dotkniętymi kwalifikowaną wadą $\mathrm{w}$ postaci wydania ich bez podstawy prawnej (jak wspomniano, do tego rodzaju wady wyrok TK w sprawie o sygn. P 46/13 w ogóle się nie odnosił). W przypadku wady decyzji polegającej na wydaniu jej bez podstawy prawnej można twierdzić, że tak określona wada ma charakter dostatecznie jednoznaczny oraz precyzyjny i nie jest opisana poprzez odwołanie się do sformułowań ocennych lub niedostatecznie konkretnych. Nie ma więc w tym wypadku większego ryzyka, że rozumienie tej wady (jako przesłanki stwierdzenia nieważności decyzji) będzie zmieniało się w czasie i będzie wzmacniało niepewność adresata danej decyzji co do przyszłego trwania (obowiązywania) tej decyzji. Ponadto można by twierdzić, że wada decyzji polegająca na wydaniu jej bez podstawy prawnej jest o wiele poważniejsza i bardziej istotna niż wada decyzji polegająca na wydaniu jej z rażącym naruszeniem prawa. W przypadku tej ostatniej wady podstawa prawna dla decyzji istnieje, choć jest niewłaściwie przez organ zastosowana, natomiast w przypadku wady polegającej na wydaniu decyzji bez podstawy prawnej mamy do czynienia z sytuacją, w której decyzja administracyjna dokonuje konkretyzacji praw i obowiązków jednostek w sposób samoistny, bez oparcia $\mathrm{w}$ jakimkolwiek przepisie prawa powszechnie obowiązującego. To zaś jest sytuacja rażąco sprzeczna z przepisami Konstytucji, które wymagają, by organy władzy publicznej działały na podstawie prawa (art. 7 Konstytucji) oraz by obowiązki jednostek były kształtowane na podstawie ustaw i innych aktów prawa powszechnie obowiązującego, a nie na podstawie samoistnej lub na podstawie aktów niemających przymiotu prawa powszechnie obowiązującego (zob. np. art. 31 ust. 1, art. 84, art. 93 ust. 2, art. 217 Konstytucji). Przy uwzględnieniu powyższych argumentów można by zatem twierdzić, że decyzje administracyjne wydane bez podstawy prawnej są przejawem na tyle ciężkiego naruszenia prawa, że upływ czasu nie powinien powodować sanowania tego rodzaju wady oraz nie powinien wywoływać u adresatów tych decyzji powstania usprawiedliwionych oczekiwań co do bezwzględnej trwałości w czasie tych decyzji, jako wyłączonych spod możliwości stwierdzenia ich nieważności. Inaczej mówiąc, przy założeniu trafności wspomnianych wyżej argumentów, jest zgodny $\mathrm{z}$ art. 2 Konstytucji stan prawny, w którym decyzje wydane bez podstawy prawnej mogą być uchylone w trybie stwierdzenia ich nieważności w każdym czasie, 
nawet jeżeli od dnia ich doręczenia lub ogłoszenia upłynął znaczny termin (chyba że dana decyzja wywołała nieodwracalne skutki prawne).

Na takim właśnie założeniu opierał się projekt zmiany Kodeksu postępowania administracyjnego przedłożony w kwietniu 2016 r. przez senacką Komisję Ustawodawczą. W uzasadnieniu do tego projektu zostało stwierdzone, że wada decyzji polegająca na jej wydaniu bez podstawy prawnej: nie może wspótistnieć z usprawiedliwionymi oczekiwaniami po stronie beneficjenta danej decyzji, a przecież to właśnie tego typu oczekiwania sa chronione $w$ ramach zasady zaufania do państwa i stanowionego przez nie prawa. Co więcej: przesłanka ujęta wart. $156 \$ 1$ pkt 2 in principio k.p.a. - w odróżnieniu od przesłanki rażacego naruszenia prawa nie cechuje się taka nieostrościa, niejednoznacznością, a jej stosowanie nie wywołuje większych kontrowersji. Wreszcie, w przekonaniu Komisji Ustawodawczej nie nadaje się do obrony teza, że na ochronę zasługuja bezprawnie nabyte uprawnienia (roszczenia). W tym zakresie zatem bezwzgledny prymat zasady praworzadności nie powinien być kwestionowany ${ }^{8}$. Dlatego też we wspomnianym projekcie senackim przesłanka przedawnienia określona w projektowanym art. $156 \S 2$ k.p.a. nadal (tak samo jak to ma miejsce de lega lata) nie miała być stosowana do decyzji wydanych bez podstawy prawnej.

Tego rodzaju stanowisko zostało wszakże poddane trafnej krytyce. W szczególności, Sąd Najwyższy w opinii do przedstawionego wyżej projektu senackiej Komisji Ustawodawczej stwierdził, że również decyzje wydane bez podstawy prawnej powinny być objęte przesłanką przedawnienia wykluczającą dopuszczalność stwierdzania ich nieważności po upływie dziesięciu lat od dnia doręczenia lub ogłoszenia danej decyzji, gdyż przemawia za tym wzgląd na pewność prawa, bezpieczeństwo obrotu prawnego oraz konieczność ochrony zaufania obywatela do państwa. Zdaniem Sądu Najwyższego w wyroku w sprawie o sygn. P 46/13 Trybunał Konstytucyjny musiał się ograniczyć jedynie do rozważenia przesłanki „rażącego naruszenia prawa” w rozumieniu art. $156 \$ 1$ pkt 2 in fine k.p.a., gdyż właśnie o to (i tylko o to) został zapytany przez sąd powszechny, aczkolwiek de lege ferenda: [p] roblem trwałości decyzji administracyjnych wymaga jednak szerszego uregulowania. Wydaje się, iż powinien on zostać rozwiązany w kierunku jak najszerszego ograniczenia czasowego możliwości stwierdzania nieważności decyzji administracyjnych. Brak tzw. przedawnienia w tym zakresie nie tylko rujnuje pewność i bezpieczeństwo obrotu prawnego w Polsce, lecz jest również niekorzystny z punktu widzenia słusznych interesów Skarbu Państwa, jednostek samorządu terytorialnego oraz osób trzecich $w$ stosunku do stron postępowania administracyjnego prowadzacego do wydania decyzji nadzorczych (np. najemców lokali $w$ nieruchomości objętej roszczeniami reprywatyzacyjnymi, którym skądinąd nie przysługuje status strony $w$ postępowaniach administracyjnych dotyczacych zwrotu nieruchomości czy też ustanowienia na niej prawa rzeczowego na rzecz

8 Druk senacki nr 154/IX kad., uzasadnienie, s. 6. 
dawnego właściciela lub jego następcy prawnego, zob. m.in. wyrok NSA z 9 października 2015 r., I OSK 1904/14, LEX nr 2002580). Dodatkowo nale ży odnotować, $\dot{z}$ e w przypadku innego, nadzwyczajnego trybu postępowania administracyjnego, a mianowicie postępowania wznowieniowego, art. $146 \$ 1$ k.p.a. jednolicie reguluje odpowiednie terminy prekluzyjne (10 lat, a niekiedy 5 lat) do wzruszenia decyzji. Trudno zrozumieć przyczyny, dla których w omawianym przypadku [tj. w przypadku stwierdzania nieważności decyzji - przyp. M.S.] ma być inaczej ${ }^{9}$.

Z powyższego założenia zdają się też wychodzić autorzy Petycji, gdyż stwierdzają, że należy podzielić stanowisko Sądu Najwyższego zaprezentowane w 2016 r. $\mathrm{w}$ toku prac nad projektem nowelizacji Kodeksu postępowania administracyjnego zgłoszonym przez senacką Komisję Ustawodawczą.

W przekonaniu autora niniejszej opinii prawnej stanowisko zajęte w omawianym zakresie przez Sąd Najwyższy - a w konsekwencji także stanowisko autorów Petycji - jest trafne merytorycznie. Wydanie decyzji bez podstawy prawnej jest, co prawda, bodaj najpoważniejszą wadą decyzji administracyjnej i w normalnych okolicznościach powinno powodować stwierdzenie nieważności takiej decyzji. Niemniej znaczny upływ czasu od doręczenia lub ogłoszenia takiej decyzji nie może powodować dalszego istnienia lub utrwalania się niepewności po stronie adresata takiej decyzji co do jej dalszych losów prawnych, gdyż byłoby to sprzeczne z wynikającą z art. 2 Konstytucji zasadą pewności prawa oraz zaufania obywatela do państwa. Nawet jeżeli konstytucyjna zasada praworządności wymaga uchylenia takiej decyzji, to jednak po upływie znacznego czasu od dnia wejścia takiej decyzji do obrotu prawnego względne pierwszeństwo należy przyznać konstytucyjnej zasadzie pewności prawa i zaufania obywatela do państwa, wyłączając możliwość stwierdzenia nieważności takiej decyzji. Warto zresztą zaznaczyć, że wykluczenie prawnej dopuszczalności stwierdzenia nieważności decyzji wydanej bez podstawy prawnej po upływie znacznego czasu od jej wydania $w$ jakiejś mierze realizuje również zasadę praworządności, gdyż jednym z aspektów zasady praworządności jest domniemanie zgodności decyzji z prawem, przemawiające za trwałością decyzji administracyjnych ${ }^{10}$. Domniemanie zgodności decyzji z prawem dotyczy zaś także decyzji wydanych bez podstawy prawnej, które przecież z tego powodu nie stają się decyzjami nieważnymi ipso iure czy też decyzjami nieistniejącymi. Należy uznać, że wykluczenie prawnej dopuszczalności stwierdzania nieważności decyzji wydanych bez podstawy prawnej po upływie dziesięciu lat od doręczenia lub ogłoszenia decyzji jest przejawem wyważonego i racjonalnego ułożenia wzajemnych relacji pomiędzy konstytucyjnymi zasadami praworządności (z jednej strony) oraz pewności prawa i zaufania obywatela do państwa ( $\mathrm{z}$ drugiej strony). Okres dziesięciu lat od dnia

9 Uwagi do senackiego projektu ustawy o zmianie ustawy - Kodeks postępowania administracyjnego, Sąd Najwyższy, Biuro Studiów i Analiz, BSA III-021-220/16, s. 4-5.

10 Wyrok TK w sprawie o sygn. akt P 46/13, pkt III.9.2 uzasadnienia. 
doręczenia lub ogłoszenia decyzji powinien być w normalnych okolicznościach w pełni wystarczający do tego, by w tym czasie dostrzec wadę decyzji polegającą na wydaniu jej bez podstawy prawnej i aby wyeliminować ją z obrotu prawnego w trybie stwierdzenia jej nieważności. Gdy tego rodzaju eliminacja nie zostanie w tym okresie przeprowadzona, względne pierwszeństwo powinna wówczas uzyskać zasada pewności prawa i zaufania obywatela do państwa, przemawiająca za stabilizacją stosunków prawnych i za niewzruszaniem decyzji, która przez tak długi okres istniała w obrocie prawnym i korzystała $\mathrm{z}$ domniemania jej legalności. Jeżeli zaś ustawodawca dojdzie do przekonania, że w pewnych szczególnych kategoriach spraw, $\mathrm{z}$ uwagi na ich specyfikę, tego rodzaju termin przedawnienia powinien być dłuższy niż dziesięcioletni lub nawet w ogóle nie powinien obowiązywać (np. w przypadku niektórych kategorii spraw reprywatyzacyjnych), to wówczas ma on zawsze możliwość ustanowienia regulacji szczególnej, stanowiącej lex specialis względem art. $156 \$ 2$ k.p.a.

Z powyższych względów należy uznać, że zaproponowane w Petycji rozwiązanie prawne, polegające na odnoszeniu przesłanki przedawnienia $\mathrm{z}$ art. $156 \$ 2$ k.p.a. również do decyzji administracyjnych wydanych bez podstawy prawnej w rozumieniu art. $156 \$ 1$ pkt 2 in principio k.p.a. (a nie tylko do decyzji administracyjnych wydanych $\mathrm{z}$ rażącym naruszeniem prawa w rozumieniu art. $156 \S 1$ pkt 2 in fine k.p.a., tak jak to przyjął TK w wyroku w sprawie o sygn. P 46/13), jest zgodne $\mathrm{z}$ art. 2 Konstytucji i może zostać uznane za optymalnie harmonizujące ze sobą kolidujące tutaj wartości.

\section{Przewidziane w Petycji zastosowanie przesłanki przedawnienia z art. $156 \S 2$ k.p.a. do decyzji niebędących podstawą nabycia prawa lub ekspektatywy}

Przewidziane w Petycji rozwiązanie prawne dotyczące przesłanki przedawnienia $\mathrm{z}$ art. $156 \$ 2$ k.p.a. jest w jeszcze jednym aspekcie szersze zakresowo niż teza omówionego wcześniej wyroku TK o sygn. P 46/13. Mianowicie, o ile Trybunał Konstytucyjny w tym wyroku uznał, że art. $156 \$ 2$ k.p.a. jest niezgodny z art. 2 Konstytucji w zakresie, w jakim nie czyni przesłanki przedawnienia przesłanką negatywną stwierdzania nieważności decyzji będących podstawą nabycia prawa lub ekspektatywy, o tyle w Petycji proponuje się, aby przewidziana w art. 156 $\$ 2$ k.p.a. przesłanka przedawnienia była przesłanką negatywną stwierdzania nieważności wszystkich decyzji administracyjnych dotkniętych którąś z kwalifikowanych wad wymienionych w art. $156 \$ 1$ pkt 1, 2, 3, 4 i 7 k.p.a., bez względu na to, czy dana decyzja jest (lub była) czy też nie jest (lub nie była) podstawą nabycia prawa lub ekspektatywy. Tym samym pod rządami przepisów proponowanych w Petycji wykluczone będzie stwierdzanie nieważności decyzji wydanych bez podstawy prawnej lub z rażącym naruszeniem prawa po upływie dziesięciu lat 
od doręczenia lub ogłoszenia danej decyzji, nawet jeżeli na podstawie danej decyzji nikt nie nabył żadnego prawa lub ekspektatywy.

Należy uznać, że rozwiązanie prawne zaproponowane w tym zakresie w Petycji jest trafne merytorycznie i zgodne z art. 2 i art. 7 Konstytucji. Za takim stanowiskiem przemawia, po pierwsze, okoliczność, że odróżnienie od siebie decyzji będących i niebędących podstawą nabycia prawa lub ekspektatywy jest trudne i problematyczne oraz, po drugie, fakt, że również w przypadku decyzji administracyjnych niebędących podstawą nabycia prawa lub ekspektatywy w pełni aktualne jest twierdzenie, iż za utrzymaniem trwałości takich decyzji po upływie znacznego czasu od ich wydania przemawia zasada pewności prawa i potrzeba stabilizacji stosunków prawnych, nawet jeżeli taka decyzja była dotknięta wadą w postaci wydania decyzji bez podstawy prawnej lub z rażącym naruszeniem prawa.

Jeżeli chodzi o definicję czy też określenie zakresu decyzji będących podstawą nabycia prawa (czyli decyzji, o których była mowa w wyroku TK o sygn. P 46/13), to trzeba uczciwie przyznać, że kwestia ta jest stosunkowo sporna i kontrowersyjna $^{11}$. Sformułowanie mówiące o "nabyciu prawa” z decyzji administracyjnej występuje w art. 155 k.p.a. [Decyzja ostateczna, na mocy której strona nabyła prawo, może być $w$ każdym czasie za zgoda strony uchylona lub zmieniona (...)] i na gruncie tego ostatniego przepisu sformułowanie to nie jest wcale rozumiane jednolicie. Z kolei w art. 154 k.p.a. występuje przeciwstawne mu treściowo pojęcie decyzji „na mocy której żadna ze stron nie nabyła prawa” i również to pojęcie nie jest traktowane jako bezsporne znaczeniowo.

Najogólniej rzecz biorąc, „nabycie prawa” z decyzji administracyjnej oznacza, że: następuje jakieś przysporzenie na rzecz określonego podmiotu w jego sferze prawnej ${ }^{12}$. Przysporzenie to jest zazwyczaj rozumiane bardzo szeroko, aczkolwiek, jak stwierdza się w doktrynie, obejmuje jedynie przysporzenia ze sfery prawa materialnego, nie zaś procesowego. Uznaje się zatem, że „nabycie prawa” (w rozumieniu art. 155 k.p.a.) obejmuje jedynie przypadki nabycia uprawnień materialnych, nie zaś uprawnień procesowych lub formalnych ${ }^{13}$. W przekonaniu autora niniejszej opinii prawnej pogląd taki jest dyskusyjny, a w każdym razie nie znajduje on wyraźnego oparcia w treści art. 155 k.p.a., a także w treści wyroku TK w sprawie o sygn. P 46/13. Ewentualne przyjęcie, że przesłanka przedawnienia $\mathrm{z}$ art. $156 \$ 2$ k.p.a. nie ma zastosowania do tych decyzji będących podstawą nabycia prawa, które przyznały jednostce pewne uprawnienia proceduralne byłoby sprzeczne z tymi uwarunkowaniami aksjologicznymi, które skło-

11 Zob. M. Szydło, Opinia prawna na temat niektórych skutków projektowanej nowelizacji przepisów art. 156 i 158 Kodeksu postępowania administracyjnego, „Zeszyty Prawnicze BAS” 2016, nr 3, s. 138-139.

12 J. Borkowski [w:] B. Adamiak, J. Borkowski, Kodeks postępowania administracyjnego. Komentarz, Warszawa 2006, s. 709.

13 Ibidem, s. 713; A. Wróbel [w:] M. Jaśkowska, A. Wróbel, Kodeks postępowania administracyjnego, op. cit., s. 919. 
niły Trybunał Konstytucyjny w wyroku w sprawie o sygn. P 46/13 do uznania za niekonstytucyjną regulację prawną nieprzewidującą wyłączenia dopuszczalności stwierdzania nieważności decyzji administracyjnych będących podstawą nabycia prawa i wydanych znaczny czas temu. Można bowiem sądzić, że konieczność stabilizacji sytuacji prawnej adresata decyzji - na którą to konstytucyjną wartość aksjologiczną powołał się we wspomnianym wyroku Trybunał - obejmuje również konieczność stabilizacji jego sytuacji procesowej (proceduralnej).

Na gruncie art. 155 k.p.a. uznaje się, że „nabyciem prawa” jest również nałożenie na stronę określonego obowiązku, gdyż obowiązek taki oznacza jednocześnie prawo do wykonywania tylko takiego, a nie innego (zakresowo lub treściowo) obowiązku ${ }^{14}$. Z drugiej wszakże strony nie brak też poglądów - zwłaszcza wypowiadanych w dawniejszej literaturze - że decyzje administracyjne nakładające na stronę wyłącznie obowiązek (zwłaszcza w rozmiarze maksymalnym określonym prawem) nie powinny być traktowane jako decyzje przyznające prawa ${ }^{15}$.

Sporne jest ponadto, czy za decyzje administracyjne powodujące „nabycie prawa" (w rozumieniu art. 155 k.p.a., a także na potrzeby ewentualnego ujęcia tej przesłanki w art. $156 \$ 2$ k.p.a.) można uznawać decyzje administracyjne deklaratoryjne, w tym stwierdzające nabycie określonych uprawnień z mocy samego prawa. Istnieją orzeczenia sądowe wykluczające decyzje administracyjne deklaratoryjne $\mathrm{z}$ zakresu pojęcia decyzji przyznających prawa ${ }^{16}$, lecz istnieją też orzeczenia sądowe wyrażające tezę odmienną ${ }^{17}$. Trudno jest więc uznać kwestię tę za ostatecznie rozstrzygniętą.

W doktrynie uznaje się, że do decyzji administracyjnych niepowodujących nabycie prawa przez stronę należą decyzje administracyjne odmowne, czyli decyzje odmawiające załatwienia sprawy zgodnie $\mathrm{z}$ wnioskiem strony, w tym odmawiające przyznania określonego uprawnienia ${ }^{18}$. Twierdzenie to jest co do za-

14 J. Borkowski [w:] B. Adamiak, J. Borkowski, Kodeks postępowania administracyjnego, op. cit., s. 711; A. Wróbel [w:] M. Jaśkowska, A. Wróbel, Kodeks postępowania administracyjnego, op. cit., s. 919; wyrok SN z 12 grudnia 1997 r., sygn. akt III RN 92/97, OSNAPiUS 1998, nr 10, poz. 290.

15 J. Borkowski, Zmiana i uchylanie ostatecznych decyzji administracyjnych, Warszawa 1967, s. 30; W. Dawidowicz, Postępowanie administracyjne. Zarys wykładu, Warszawa 1983, s. 227-228.

16 Wyroki NSA z: 1 marca 1996 r., sygn. akt III SA 362/95, „Monitor Podatkowy” 1997, nr 3, s. 78; 31 sierpnia 1995 r., sygn. akt SA/Po 313-314/95, z glosą J. Borkowskiego, "Glosa” 1996, nr 12, s. 14 i n.

17 Wyrok NSA z 17 stycznia 1996 r., sygn. akt III SA 892/95, „Monitor Podatkowy” 1997, $\mathrm{nr} 2$, s. 52. Na rozbieżności istniejące $\mathrm{w}$ tym zakresie w orzecznictwie sądowym zwrócono również uwagę w wyroku WSA w Warszawie z 9 października 2012 r., sygn. akt III SA/Wa 3304/11, pkt 28 uzasadnienia.

18 W. Dawidowicz, Postępowanie administracyjne, op. cit., s. 227-228; J. Borkowski [w:] B. Adamiak, J. Borkowski, Kodeks postępowania administracyjnego, op. cit., s. 698- 
sady słuszne, aczkolwiek w pewnych szczególnych konstelacjach również i tego rodzaju odmowne decyzje administracyjne można by traktować jako decyzje przyznające prawa. Może tak być mianowicie w przypadkach, gdy w danym postępowaniu administracyjnym występuje więcej niż jedna strona i gdy strony tego postępowania mają przeciwstawne interesy (chodzi zatem o postępowanie, którego przedmiotem jest sprawa wielopodmiotowa $)^{19}$. W takim postępowaniu dla jednej strony decyzja odmowna (np. odmawiająca przyznania zezwolenia na określoną działalność lub odmawiająca pozwolenia na budowę) może nie wiązać się z przyznaniem jej jakichkolwiek praw, natomiast dla drugiej strony ta sama decyzja może oznaczać przyznanie jej określonego prawa, a mianowicie prawa do nieingerowania $\mathrm{w}$ jej sferę prawną przez drugą stronę tego postępowania za pomocą działań, które spotkały się z odmową organu administracji.

Trzeba też zauważyć, że nawet jeżeli na podstawie danej decyzji administracyjnej nie następuje nabycie prawa przez stronę lub strony tej decyzji, nie oznacza to wcale, że na podstawie tej decyzji nikt inny nie nabył żadnego prawa. W szczególności decyzje nakładające na stronę określony obowiązek mogą być traktowane jako jednocześnie przyznające określone skorelowane z tym obowiązkiem prawo na rzecz innych osób niż strona, w tym zwłaszcza na rzecz podmiotów zbiorowych (państwo, jednostka samorządu terytorialnego) ${ }^{20}$. Także i ta okoliczność powoduje, iż pojęcie decyzji będących podstawą nabycia prawa staje się nie dość ostre ( $w$ tym sensie, że nie jest to kategoria pojęciowa o jasno sprecyzowanych granicach), zaś ewentualne posłużenie się tym pojęciem w art. $156 \$ 2$ k.p.a. (w kontekście przesłanki przedawnienia stwierdzania nieważności decyzji) mogłoby powodować w swoim następstwie liczne spory interpretacyjne.

Również pojęcie decyzji będących podstawą nabycia ekspektatywy (do którego to pojęcia odwoływał się TK w wyroku w sprawie o sygn. P 46/13) nie może być uznane za w pełni jasne i jednoznaczne. Najogólniej rzecz biorąc, ekspektatywa (prawa) jest to oczekiwanie prawne, czyli sytuacja przejściowa, tymczasowa, jeszcze nie w pełni ukształtowana, ale prowadząca w przyszłości - po spełnieniu wielu warunków, realizowanych w pewnych odstępach czasu, sukcesywnie - do powstania prawa podmiotowego. Aby zatem można było mówić o ekspektatywie, to przynajmniej jedna $\mathrm{z}$ (ustawowych) przesłanek nabycia prawa podmiotowego musi zostać spełniona, a co najmniej jedna - nie. Musi więc istnieć w obowiązującej regulacji prawnej po stronie potencjalnych jej adresatów sytuacja dająca pewną perspektywę, szansę nabycia prawa, która po przystąpieniu przez zainte-

700; A. Wróbel [w:] M. Jaśkowska, A. Wróbel, Kodeks postępowania administracyjnego, op. cit., s. 910-911.

19 Na temat sprawy wielopodmiotowej zob. T. Kiełkowski, Sprawa administracyjna, Zakamycze 2004, s. 46-47.

20 T. Kiełkowski, Nabycie prawa na mocy decyzji administracyjnej, Warszawa 2012, s. 238-239. 
resowanych do realizacji określonych przez ustawodawcę przesłanek prowadzi do nabycia prawa ${ }^{21}$.

W tym kontekście nie jest wszakże pewne, czy pojęcie ekspektatywy prawa, do którego nawiązywał TK w wyroku w sprawie o sygn. akt P 46/13 i które ewentualnie pojawiłoby się w przepisie art. $156 \$ 2$ k.p.a. w kontekście przesłanki przedawnienia, obejmuje (lub powinno obejmować) wszelkie ekspektatywy czy też tylko ekspektatywy maksymalnie ukształtowane ${ }^{22}$. Pojęcie ekspektatywy maksymalnie ukształtowanej występuje w orzecznictwie Trybunału Konstytucyjnego (choć nie pojawiło się w wyroku w sprawie o sygn. P 46/13) i jest w tym orzecznictwie rozumiane jako sytuacja prawna, w której wprawdzie nie doszło jeszcze do wydania aktu przyznającego prawo ani stwierdzającego przysługiwanie prawa, ale spełnione zostały wszystkie (zasadnicze) przesłanki warunkujące nabycie danego prawa i brak jest tylko ostatniego etapu decydującego o definitywnym przejściu prawa podmiotowego na osobę oczekującą ${ }^{23}$. Tak rozumiana ekspektatywa maksymalnie ukształtowana (lub maksymalnie określona) jest zatem czymś więcej (czymś dalej idącym) niż zwykła ekspektatywa prawa.

Warto ponadto zauważyć, że w razie ewentualnego odwołania się przez ustawodawcę w art. $156 \$ 2$ k.p.a. (w kontekście przesłanki przedawnienia stwierdzania nieważności decyzji) do pojęcia decyzji będących podstawą nabycia ekspektatywy pojawiłyby się nieuchronnie wątpliwości interpretacyjne, czy chodzi w tym wypadku jedynie o decyzje, które podstawą ekspektatywy są nadal (cały czas), w tym również po upływie znacznego czasu (np. dziesięciu lat) od dnia ich wydania, czy też również o decyzje, które podstawą ekspektatywy były w przeszłości, lecz dana ekspektatywa już wygasła i nie przerodziła się w prawo nabyte na podstawie decyzji ${ }^{24}$.

Ponieważ więc - jak wynika z powyższych rozważań - pojęcie decyzji będących podstawą nabycia prawa lub ekspektatywy nie jest jednoznaczne i może budzić wiele kontrowersji interpretacyjnych, lepiej jest z praktycznego punktu widzenia nie wprowadzać takiego pojęcia do treści art. $156 \$ 2$ k.p.a. (w kontekście przesłanki przedawnienia stwierdzania nieważności decyzji). Lepiej jest więc przyjąć, że przesłanka przedawnienia z art. $156 \$ 2$ k.p.a. ma jednolite zasto-

21 Wyrok NSA z 28 kwietnia 2015 r., sygn. akt II GSK 276/14.

22 Zob. M. Szydło, Opinia prawna na temat niektórych skutków, op. cit., s. 141.

23 Wyroki TK z: 3 listopada 1998 r., sygn. akt SK 7/98, OTK ZU 1998, nr 7, poz. 114, pkt III.1 uzasadnienia; 22 czerwca 1999 r., sygn. akt K 5/99, OTK ZU 1999, nr 5, poz. 100, pkt III.3 uzasadnienia; 24 października 2000 r., sygn. akt SK 7/00, OTK ZU 2000, nr 7, poz. 256, pkt III.3-4 uzasadnienia; 19 grudnia 2002 r., sygn. akt K 33/02, OTK-A ZU 2002, nr 7, poz. 97, pkt III.8 uzasadnienia; 10 kwietnia 2006 r., sygn. akt SK 30/04, OTK-A ZU 2006, nr 4, poz. 42, pkt III.3.2 uzasadnienia; wyrok NSA z 28 kwietnia 2015 r., sygn. akt II GSK 276/14; zob. też M. Jackowski, Ekspektatywa jako przedmiot ochrony konstytucyjnej, „Państwo i Prawo” 2007, z. 11, s. 96 i n.

24 Por. M. Szydło, Opinia prawna na temat niektórych skutków, op. cit., s. 142. 
sowanie do wszelkich decyzji dotkniętych określonymi kwalifikowanymi wadami, bez względu na to, czy dana decyzja jest (lub była) podstawą nabycia prawa lub ekspektatywy.

Za tego rodzaju stanowiskiem przemawia również okoliczność, że utrzymywanie trwałości wadliwych decyzji administracyjnych niebędących podstawą nabycia prawa lub ekspektatywy, a wydanych wiele lat temu w przeszłości, jak najbardziej znajduje swoje uzasadnienie w konstytucyjnej zasadzie pewności prawa i zaufania obywatela do państwa. Ta konstytucyjna zasada (czy też zasady) odnosi się do wszelkich działań państwa, w tym do wszelkich jego władczych wypowiedzi w formie decyzji administracyjnych, bez względu na to, czy na podstawie danego działania państwa, w tym decyzji administracyjnej, ktokolwiek nabył określone prawo lub ekspektatywę $\mathrm{w}$ technicznoprawnym rozumieniu tych pojęć. Każda bowiem decyzja administracyjna, będąca przejawem władczej konkretyzacji przez organ państwa określonych norm ustawowych, powoduje wprowadzenie do obrotu prawnego określonej normy lub norm indywidualno-konkretnych, co do których uczestnicy obrotu prawnego (nie tylko zatem bezpośredni adresat decyzji) działają w zaufaniu i opierają na nich swoje zachowania oraz oczekiwania prawne. Każda zatem decyzja administracyjna, w tym także decyzja nieprzyznająca żadnych praw lub niepowodująca powstania ekspektatywy w ścisłym znaczeniu tych słów, powoduje powstanie u uczestników obrotu prawnego określonych oczekiwań, a mianowicie oczekiwań, że w ten sposób skonkretyzowane normy ustawowe będą rozstrzygnięciem trwałym i stabilnym i że konkretyzacja taka jest zgodna z obiektywnym porządkiem prawnym. Tego rodzaju uzasadnione oczekiwanie prawne jednostek powinno być $\mathrm{w}$ państwie prawnym chronione i powinno ono powodować niedopuszczalność wzruszenia wadliwej decyzji administracyjnej po upływie odpowiednio długiego czasu od dnia jej wydania.

Warto przy tym pamiętać, że motywowana pewnością prawa i ochroną zaufania obywatela do państwa niedopuszczalność stwierdzenia nieważności decyzji administracyjnej dotkniętej kwalifikowaną wadą po upływie dziesięciu lat od dnia jej doręczenia lub ogłoszenia nie wyklucza bynajmniej przyznawania określonych rekompensat dla osoby, która $\mathrm{z}$ tytułu wydania lub wykonywania danej decyzji poniosła określoną szkodę. Kodeks postępowania administracyjnego oraz Kodeks cywilny umożliwiają bowiem takiej osobie uzyskanie w określonym trybie należnego jej odszkodowania ${ }^{25}$. Z kolei jeżeli wskutek proponowanego w Petycji zmienionego art. $156 \$ 2$ k.p.a. nie będzie dopuszczalne po dziesięciu latach stwierdzenie nieważności takiej decyzji wydanej bez podstawy prawnej lub z rażącym naruszeniem prawa, która była decyzją odmowną i która dlatego nie była podstawą nabycia prawa lub ekspektatywy, to adresat tego rodzaju

25 Zob. art. $158 \$ 2$ k.p.a. oraz art. 417 i art. $417^{1} \S 2$ ustawy z 23 kwietnia 1964 r. - Kodeks cywilny, t.j. Dz.U. 2017, poz. 459, ze zm. 
decyzji odmownej nie tylko będzie mógł domagać się od państwa stosownego odszkodowania, ale teoretycznie będzie miał również możliwość ponownego starania się o uprawnienia lub o dobro, których przyznania odmówiono mu poprzednią decyzją administracyjną (wydaną więcej niż dziesięć lat wcześniej). Tak więc wyłączenie prawnej możliwości stwierdzania nieważności wspomnianej decyzji nie pozostawi zainteresowanego obywatela (lub innej jednostki) w prawnej próżni i bez żadnych zabezpieczeń.

Ostatecznie można zatem uznać, że zaproponowane w Petycji rozwiązanie prawne, polegające na odnoszeniu przesłanki przedawnienia $z$ art. $156 \$ 2$ k.p.a. również do takich decyzji administracyjnych wydanych bez podstawy prawnej lub z rażącym naruszeniem prawa, które nie były podstawą nabycia prawa lub ekspektatywy (inaczej zatem niż przyjął TK w wyroku o sygn. P 46/13), jest zgodne $\mathrm{z}$ art. 2 Konstytucji i może zostać uznane za optymalnie harmonizujące ze sobą kolidujące tutaj wartości (tj. zasadę praworządności oraz zasadę pewności prawa oraz zaufania obywatela do państwa).

\section{Uwagi na temat proponowanego w Petycji art. 158 § 3 k.p.a.}

W Petycji występuje słuszny postulat, aby do Kodeksu postępowania administracyjnego został wprowadzony przepis, zgodnie z którym wydanie decyzji stwierdzającej wydanie zaskarżonej decyzji administracyjnej z naruszeniem prawa (co następuje na podstawie art. $158 \$ 2$ k.p.a.) będzie stanowiło podstawę do stwierdzenia wydania z naruszeniem prawa również tej decyzji administracyjnej, która została wydana na podstawie takiej zaskarżonej decyzji (art. $158 \$ 3$ k.p.a. w brzmieniu proponowanym w Petycji). Proponowany w Petycji art. $158 \$ 3$ k.p.a. odnosi się do sytuacji, w których nie można stwierdzić nieważności zaskarżonej decyzji administracyjnej $\mathrm{z}$ uwagi na wystąpienie którejś z negatywnych przesłanek określonych w art. $156 \$ 2$ k.p.a. (tj. przesłanki przedawnienia lub przesłanki nastąpienia nieodwracalnych skutków prawnych decyzji) i gdy organ administracji jest zobowiązany do wydania decyzji stwierdzającej wydanie zaskarżonej decyzji z naruszeniem prawa (na podstawie art. $158 \$ 2$ k.p.a.). W takim wypadku nadal będzie pozostawała w mocy i nadal będzie prawnie wiążąca nie tylko zaskarżona decyzja administracyjna (tj. ta, której nieważności nie można stwierdzić z uwagi na wystąpienie którejś z przesłanek negatywnych określonych w art. $156 \$ 2$ k.p.a.), ale również każda inna decyzja administracyjna, która została wydana na podstawie tej pierwszej (zaskarżonej) decyzji administracyjnej, a więc każda decyzja administracyjna, dla której ta pierwsza decyzja stanowiła merytoryczne czy też prawne uzasadnienie (umocowanie). Gdyby pierwsza ze wspomnianych decyzji (tj. zaskarżona decyzja) została uchylona wskutek stwierdzenia jej nieważności, to wówczas w odniesieniu do każdej innej decyzji administracyjnej wydanej na podstawie takiej (uchylonej) decyzji administracyjnej 
można by wszcząć postępowanie wznowieniowe zgodnie z art. $145 \$ 1$ pkt 8 k.p.a. i w rezultacie można by tę drugą decyzję administracyjną uchylićc ${ }^{26}$. Jeżeli jednak $\mathrm{z}$ uwagi na wystąpienie którejś z negatywnych przesłanek określonych w art. 156 $\$ 2$ k.p.a. nie jest prawnie dopuszczalne stwierdzenie nieważności zaskarżonej decyzji administracyjnej, wówczas ewentualne wydanie decyzji stwierdzającej wydanie tej pierwszej decyzji z naruszeniem prawa nie wpływa de lege lata na los prawny innych decyzji administracyjnych, wydanych na podstawie tej pierwszej zaskarżonej decyzji. W Petycji słusznie się proponuje, aby w takim wypadku dopuszczalne prawnie było wydanie decyzji administracyjnej stwierdzającej wydanie tej innej decyzji administracyjnej z naruszeniem prawa (projektowany w Petycji art. $158 \$ 3$ k.p.a.). Pozwoli to zainteresowanym osobom m.in. na ubieganie się uzyskania stosownego odszkodowania na podstawie przepisów Kodeksu cywilnego.

W odniesieniu do proponowanego w Petycji przepisu art. $158 \S 3$ k.p.a. należałoby wszakże zgłosić dwa formalne zastrzeżenia.

Po pierwsze, w proponowanym w Petycji art. $158 \$ 3$ k.p.a. dwukrotnie użyto sformułowania „decyzja administracyjna”, podczas gdy w pełni wystarczyłoby posłużenie się w tym kontekście określeniem „decyzja”. Pojęcie „decyzji administracyjnej” występuje w Kodeksie postępowania administracyjnego tylko w art. 1 pkt 1 (oraz w art. 268a), natomiast we wszystkich innych przepisach tego Kodeksu ustawodawca posługuje się jednolicie pojęciem „decyzji” (na oznaczenie indywidualnego aktu administracyjnego rozstrzygającego co do istoty sprawę administracyjną lub dokonującego umorzenia postępowania administracyjnego). Również więc w projektowanym art. $158 \$ 3$ k.p.a. powinno de lege ferenda występować pojęcie „decyzji”.

Po drugie, w projektowanym art. $158 \$ 3$ in fine k.p.a. w miejsce występującego tam sformułowania „na podstawie” powinno się użyć zwrotu „w oparciu”; zamiast więc sformułowania: „decyzji administracyjnej, która została wydana na podstawie takiej zaskarżonej decyzji”, powinno się tu pojawić sformułowanie: „decyzji, która została wydana w oparciu o taką zaskarżoną decyzję”. Proponowane w niniejszej opinii prawnej sformułowanie „w oparciu” nawiązywałoby do treści art. $145 \$ 1$ pkt 8 k.p.a., gdzie jest mowa o analogicznej sytuacji, tj. o sytuacji, gdy jedna z decyzji administracyjnych stanowi swoiste uzasadnienie czy też umocowanie dla wydania drugiej decyzji administracyjnej. W Kodeksie postępowania administracyjnego (tak samo jak w każdej innej ustawie) takie same czy też analogiczne sytuacje powinny być opisywane za pomocą tych samych słów czy też określeń, aby nie wywoływać zbędnych wątpliwości interpretacyjnych. Nawet więc jeżeli w sensie semantycznym określenie „na podstawie”

26 Art. $145 \$ 1$ pkt 8 k.p.a stanowi, że: W sprawie zakończonej decyzja ostateczna wznawia się postępowanie, jeżeli [...] 8) decyzja została wydana w oparciu o inną decyzję lub orzeczenie sądu, które zostało następnie uchylone lub zmienione. 
nie różni się znaczeniowo od określenia „w oparciu”, to jednak z uwagi na konieczność zachowania wewnętrznej spójności przepisów Kodeksu postępowania administracyjnego oraz w celu ułatwienia stosowania wykładni systemowej wewnętrznej przepisów tego Kodeksu należałoby postulować użycie w projektowanym przepisie art. $158 \$ 3$ k.p.a. takiego samego określenia, jakiego użyto w art. $145 \$ 1$ pkt 8 k.p.a. Pozwoli to na odwoływanie się przy wykładni przyszłego art. $158 \$ 3$ k.p.a. do orzecznictwa ukształtowanego na gruncie art. 145 $\$ 1$ pkt 8 k.p.a. ${ }^{27}$.

${ }^{27} \mathrm{~W}$ odniesieniu do występującego w art. $145 \$ 1$ pkt 8 k.p.a. zwrotu „w oparciu” w orzecznictwie sądowoadministracyjnym stwierdza się co następuje: Nie może być wątpliwości co do tego, iż sednem przesłanki przewidzianej $w$ art. $145 \$ 1$ pkt. 8 k.p.a., jest to, aby obejmowana procedura wznowienia postępowania decyzja administracyjna została wydana „w oparciu” o rozstrzygnięcie organu administracyjnego bądź sądu administracyjnego, które zostało następnie uchylone lub zmienione. Językowy sens pojęcia „w oparciu”, można przy tym scharakteryzować zwrotem: „na podstawie”, co wprost wskazuje, iż jakaś rzecz/stan (tu decyzja) znajduje uzasadnienie czy wręcz merytoryczne umocowanie $w$ jakiejś innej rzeczy/stanie (również decyzji). Pojęcie użyte przez ustawodawcę $w$ art. $145 \$ 1$ pkt. 8 k.p.a. należy zatem rozumieć szeroko, jako związek pomiędzy decyzjami bądź decyzjami i orzeczeniem sądu administracyjnego. Nie można $w$ związku $z$ tym podzielić zapatrywania autora skargi kasacyjnej, który $w$ istocie dowodzi, iż unormowanie z art. $145 \$ 1$ pkt. 8 k.p.a. dotyczy wyłacznie takich sytuacji, $w$ których uchylona lub zmieniona decyzja organu bądź orzeczenie sądu administracyjnego stanowiło podstawę wydania innej decyzji tzw. decyzji zależnej, przy czym podstawa ta musi wynikać z konkretnych przepisów administracyjnego prawa materialnego. Choć niewątpliwie opisana zależność mieści się w dyspozycji art. $145 \$ 1$ pkt. 8 k.p.a., to jednak nie jest jedyna i wyłaczna. Powołując się na pogląd wyrażony w orzeczeniu NSA z dnia 9 listopada 1998 r. (sygn. akt OPK 4-7/98 opubl. w ONSA 1999/1/13), skarżący stwierdza, iż w sprawie nie występuje konstrukcja decyzji zależnej, a zatem art. $145 \$ 1$ pkt. 8 k.p.a. nie mógtby znaleźć zastosowania. Zauważyć należy, iż związek, o którym mówi art. $145 \$ 1$ pkt. 8 k.p.a., można zobrazować jako pewna sekwencje „działań prawnych” organu administracyjnego, zgodnie z logiką których, jedna decyzja lub orzeczenie sądu stanowi podstawę wydania innej decyzji (ta druga decyzja zależna jest od decyzji pierwszej). Podkreślić przy tym trzeba, iż wydanie drugiej decyzji, nie będzie możliwe bez wcześniejszego wydania decyzji pierwszej. Przykłady tego typu „sekwencyjnych” działań prawnych organów przewiduja chociażby przepisy ustawy Prawo budowlane (np. decyzja o ustaleniu lokalizacji inwestycji celu publicznego musi poprzedzić decyzję o pozwoleniu na budowę). Takie działania wynikaja również $z$ istoty decyzji kasatoryjnych, zawierajacych wytyczne co do dalszego postępowania [...]. Niewatpliwa waga nadana przez ustawodawcę wcześniejszej decyzji przejawia się $w$ tym, iż po wyeliminowaniu jej z obrotu prawnego, wydana na jej podstawie decyzja, również traci swoje uzasadnienie i rację bytu. Klasyczna konstrukcja decyzji zależnej, która przywołuje wnoszący skargę kasacyjną, bazuje na pojęciu zależności wynikajacej wprost z przepisów prawa administracyjnego. Jednakże jak wspomniano, nie wyczerpuje to zakresu pojęcia „w oparciu” użytego w art. $145 \$ 1$ pkt. 8 k.p.a. W jego skład wcho- 


\section{Zasadność proponowanej w Petycji regulacji intertemporalnej}

W Petycji zasadnie proponuje się przyjęcie regulacji intertemporalnej, zgodnie z którą: [d]o postępowań o stwierdzenie nieważności wszczętych przed wejściem $w$ życie niniejszej ustawy [tj. ustawy proponowanej w Petycji - przypis M.S.] stosuje się przepisy dotychczasowe. Tego rodzaju reguła intertemporalna ma swoje uzasadnienie w zasadach prawa administracyjnego intertemporalnego i jest stosunkowo często wykorzystywana w praktyce przez ustawodawcę ${ }^{28}$. Reguła ta została też przez twórców Petycji sformułowana zgodnie z Zasadami techniki prawodawczej $^{29}$. Niemniej należy zauważyć, że w razie przyjęcia przez ustawodawcę tego rodzaju reguły intertemporalnej, po wejściu w życie znowelizowanego Kodeksu postępowania administracyjnego będzie dopuszczalne dalsze stwierdzanie nieważności decyzji administracyjnych w takich sytuacjach, w których w myśl wyroku TK w sprawie o sygn. P 46/13 jest to niezgodne $z$ art. 2 Konstytucji. Aby zapobiec dalszemu trwaniu stanu uznanego przez TK za niezgodny $\mathrm{z}$ art. 2 Konstytucji, ustawodawca może więc przyjąć również inną regułę intertemporalną, a mianowicie regułę nakazującą stosowanie nowego prawa również do postępowań o stwierdzenie nieważności wszczętych przed wejściem w życie ustawy postulowanej w Petycji.

\section{Podsumowanie}

Podsumowując, należy stwierdzić, że załączony do opiniowanej Petycji projekt ustawy o zmianie ustawy - Kodeks postępowania administracyjnego powinien być przedmiotem prac parlamentarnych. Proponowana w opiniowanej Petycji treść art. $156 \$ 2$ k.p.a. jest zgodna $\mathrm{z}$ art. 2 Konstytucji oraz proponowany nowy przepis art. $158 \$ 3$ k.p.a. jest zasadny merytorycznie.

dza zatem zarówno związki decyzji wynikające wprost z przepisów prawa materialnego np. omówiona już zależność decyzji o pozwoleniu na budowę od decyzji o ustaleniu lokalizacji inwestycji celu publicznego, jak i zależność (związek o charakterze procesowym) spowodowana wyeliminowaniem z obrotu prawnego wcześniejszej decyzji kasatoryjnej (np. decyzji organu odwoławczego uchylającej decyzję administracyjna organu pierwszej instancji), na podstawie której $i w$ wykonaniu zaleceń której wydane zostały inne decyzje, wyrok NSA z 10 października 2006 r., sygn. akt II GSK 156/06. Zob. M. Kamiński, Prawo administracyjne intertemporalne, Warszawa 2011, s. 388 i n. Zob. $\$ 31$ ust. $1 \mathrm{w}$ związku z $\$ 30$ ust. 2 pkt 1 Zasad techniki prawodawczej, stanowiących załącznik do rozporządzenia Prezesa Rady Ministrów z 20 czerwca 2002 r. w sprawie „Zasad techniki prawodawczej”, t.j. Dz.U. 2016, poz. 283. 


\section{Bibliografia}

Borkowski J. [w:] Adamiak B., Borkowski J., Kodeks postępowania administracyjnego. Komentarz, Warszawa 2006.

Borkowski J., Zmiana i uchylanie ostatecznych decyzji administracyjnych, Warszawa 1967.

Dawidowicz W., Postępowanie administracyjne. Zarys wykładu, Warszawa 1983.

Jackowski M., Ekspektatywa jako przedmiot ochrony konstytucyjnej, „Państwo i Prawo” 2007, z. 11.

Jaśkowska M., Wróbel A., Kodeks postępowania administracyjnego. Komentarz Lex, Warszawa 2011.

Kamiński M., Nieważność decyzji administracyjnej. Studium teoretyczne, Warszawa-Kraków 2006.

Kamiński M., Prawo administracyjne intertemporalne, Warszawa 2011.

Kiełkowski T., Nabycie prawa na mocy decyzji administracyjnej, Warszawa 2012.

Kiełkowski T., Sprawa administracyjna, Zakamycze 2004.

Szydło M., Opinia prawna na temat niektórych skutków projektowanej nowelizacji przepisów art. 156 i 158 Kodeksu postępowania administracyjnego, „Zeszyty Prawnicze BAS” 2016, nr 3.

Tuleja P., Zaniechanie ustawodawcze [w:] Ustroje, doktryny, instytucje polityczne. Księga jubileuszowa Profesora zw. dra hab. Mariana Grzybowskiego, red. J. Czajowski, Kraków 2007.

Woś T., Wyroki interpretacyjne i zakresowe w orzecznictwie Trybunału Konstytucyjnego, „Studia Iuridica Lublinensia” 2016, t. XXV, nr 3, https://doi.org/10.17951/ sil.2016.25.3.985.

Zdyb M., Stelmasiak J., Zasady ogólne kodeksu postępowania administracyjnego, Lublin 1999. 